\title{
Antioxidant enzymes activities in obese Tunisian children
}

\author{
Sonia Sfar ${ }^{1 *}$, Raoudha Boussoffara ${ }^{2}$, Mohamed Tahar Sfar ${ }^{1,2}$ and Abdelhamid Kerkeni ${ }^{1}$
}

\begin{abstract}
Background: The oxidant stress, expected to increase in obese adults, has an important role in the pathogenesis of many diseases. It results when free radical formation is greatly increased or protective antioxidant mechanisms are compromised. The main objective of this study is to evaluate the antioxidant response to obesity-related stress in healthy children.

Methods: A hundred and six healthy children (54 obese and 52 controls), aged 6-12 years old, participated in this study. The collected data included anthropometric measures, blood pressure, fasting glucose, total cholesterol, triglycerides and enzymatic antioxidants (Superoxide dismutase: SOD, Catalase: CAT and Glutathione peroxidase: GPx).

Results: The first step antioxidant response, estimated by the SOD activity, was significantly higher in obese children compared with normal-weight controls $(p<0.05)$. Mean activities of anti-radical GPx and CAT enzymes were not affected by the BMI increase. Although, total cholesterol levels were statistically higher in the obese group, there was no significant association with the SOD activity.

Conclusions: The obesity-related increase of the oxidant stress can be observed even in the childhood period. In addition to the complications of an increased BMl, obesity itself can be considered as an independent risk factor of free radical production resulting in an increased antioxidant response.
\end{abstract}

Keywords: Catalase, Glutathione peroxidase, Superoxide dismutase, Obesity, Oxidant stress, Children

\section{Background}

Obesity has become a major health problem in both developed and under-developed countries. It is a complex disease that involves the interactions between environmental [1] and genetic factors [2]. The prevalence of obesity has increased at an alarming rate during the last three decades, and has been particularly problematic in children [3]. The main direct adverse effects of childhood obesity include orthopedic complications, sleep apnea, and psychological disorders [4]. Approximately $70 \%$ of obese adolescents grow up to become obese adults [5].

Defining the basic physiopathology of childhood obesity should be the first step in preventing the associated consequences that may develop lifelong. In particular, the cellular defense mechanisms and their influence against many diseases were thought to be related to

\footnotetext{
* Correspondence: sonia_sfar@yahoo.fr

'Unité de recherche «Eléments trace, radicaux libres, systèmes antioxydants et pathologies humaines», Faculté de médecine de Monastir, Université de Monastir, rue Avicenne, 5019, Monastir, Tunisia

Full list of author information is available at the end of the article
}

obesity and its complications as seen in adults [6]. Cells have developed an enzymatic antioxidant pathway against reactive oxygen species (ROS) that are generated during oxidative metabolism: first, the dismutation of superoxide anion $\left(\mathrm{O}_{2}^{-}\right)$to hydrogen peroxide $\left(\mathrm{H}_{2} \mathrm{O}_{2}\right)$ catalyzed by superoxide dismutase (SOD); and then, the conversion of $\mathrm{H}_{2} \mathrm{O}_{2}$ to $\mathrm{H}_{2} \mathrm{O}$ by glutathione peroxidase (GPx) or catalase (CAT). The activity of first- and second-step antioxidant enzymes must be balanced to prevent oxidative damage in cells, which may contribute to various pathological processes [7]. Compared to adult studies, the knowledge about the response to oxidant stress damage caused by obesity during childhood is limited.

The present work aimed at investigating the effect of the childhood obesity on the antioxidant enzyme activities (SOD, GPx and CAT).

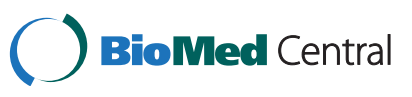

(c) 2013 Sfar et al.; licensee BioMed Central Ltd. This is an Open Access article distributed under the terms of the Creative Commons Attribution License (http://creativecommons.org/licenses/by/2.0), which permits unrestricted use, distribution, and reproduction in any medium, provided the original work is properly cited. 


\section{Methods}

\section{Subjects}

The study population consisted of 106 healthy children, aged between 6 and 12 years old: 54 exogenic obese children ( 31 girls and 23 boys) and 52 controls ( 25 girls and 27 boys). The recruitment was performed between January 2012 and March 2012, from 25 elementary schools in the district of Mahdia (eastern central coast of Tunisia), which included a mixture of rural and urban environments. Obesity diagnosis was obtained according to the body mass index scale, and a percentile more than 95\% was considered [8,9]. Endogenic obesity (hypothyroidism, Cushing's syndrome) and genetic syndromes (Alström, Bardet-Biedl) were ruled out by physical examination and laboratory tests. Chronic diseases like diabetes, hepatitis, epilepsy, and renal diseases, were included in the exclusion criteria. The control group was selected from healthy children without any complaint and normal physical examination with normal laboratory findings. Taking into account gender- and age-related variations of children growth rate (in weight, height and body mass index) [9], both gender populations were divided into two groups: 6-8.5 and 9-12 years old.

Age, sex, weight including light clothing $( \pm 0.1 \mathrm{~kg})$, height without shoes $( \pm 0.1 \mathrm{~cm})$ and body mass index (weight/height ${ }^{2}$ ) of all children were recorded. Waist and hip circumferences were measured using a tape measure to the nearest $1 \mathrm{~mm}$. Waist circumference was measured midway between the lowest rib and the superior border of iliac crest at the end of normal expiration. Hip circumference was measured at the level of widest portion of buttocks (trochanters). Blood pressure was measured using a mercury sphygmomanometer. The measurements were done after $30 \mathrm{~min}$ of resting, on both arms. The highest value of pressure was considered for every child. The children were carefully instructed to fast for a period of at least $12 \mathrm{~h}$. A parental consent was obtained from every child included in the study population. The local ethical committee of the hospital of Mahdia approved the study protocols.

\section{Blood samples collection}

A venous blood sample was obtained from every fasting volunteer into heparinized tubes (BD Vacutainer System). All the blood samples were immediately carried to the laboratory of the academic hospital of Mahdia in a crushed ice block. Erythrocytes and plasma were separated by centrifugation at $3600 \mathrm{~g}$ for $10 \mathrm{~min}$, aliquoted, coded, frozen and stored at $-20^{\circ} \mathrm{C}$ until analysis. In addition to the assays described below, other biochemical measurements including fasting plasma glucose, plasma total cholesterol and plasma triglycerides were performed.

\section{Antioxidant enzymes activity}

The activity of anti-radical enzymes, namely the superoxide dismutase (SOD), the catalase (CAT), and the glutathione peroxidase (GPx) was determined by spectrophotometry (spectrophotometer Shimadzu 160 A). Hemoglobin concentration was estimated in every blood sample from the absorbance measurement at $546 \mathrm{~nm}$ (The colorimetric method). Set solutions were prepared using $20 \mu \mathrm{L}$ from $1 / 10$ diluted erythrocytes and $1 \mathrm{~mL}$ from diluted Drabkin solution (0.77 $\mathrm{mM} \mathrm{KCN}, 0.6 \mathrm{mM} \mathrm{K}_{3}\left(\mathrm{Fe}(\mathrm{CN})_{6}\right)$ and $0.01 \mathrm{M} \mathrm{K}$ $\left.\left(\mathrm{H}_{2} \mathrm{PO}_{4}\right)\right)$.

The SOD activity was determined in erythrocytes using pyrogallol as a substrate by the method of Marklund and Marklund [10]. This method is based on pyrogallol oxidation by the superoxide anion $\left(\mathrm{O}_{2}^{-}\right)$and its dismutation by SOD enzyme. Red blood cells were first hemolysed with cold distilled water. After extraction with ethanol/chloroform mixture (1:1) followed by centrifugation at $3600 \mathrm{rpm}$ at $4^{\circ} \mathrm{C}$ during $25 \mathrm{~min}$, the organic phase was collected. A mixture $(935 \mu \mathrm{L}$ of Tris tampon and $40 \mu \mathrm{L}$ of pyragollol) was then added to $25 \mu \mathrm{L}$ of the $(1 / 2)$ diluted organic phase solution. The enzymatic activity, in units per milligrams of hemoglobin $(\mathrm{U} / \mathrm{mg} \mathrm{Hb})$, was measured in the supernatant at $420 \mathrm{~nm}$ according to Winterbourn et al. [11]. A unit of SOD activity corresponds to the least enzyme quantity able to inhibit the auto-oxidation reaction of the added pyragollol at $50 \%$. Results were expressed as $\mathrm{U}(\mathrm{SOD}) / \mathrm{mg} \mathrm{Hb}$.

CAT activity $(\mathrm{U} / \mathrm{g} \mathrm{Hb})$ was estimated in erythrocytes according to the method of Beers and Sizer [12] using hydrogen peroxide as a substrate. The method is based on the decomposition of hydrogen peroxide which is indicated by the decrease in absorbance at $240 \mathrm{~nm}$ [13]. To obtain the assay solution, $2.9 \mathrm{~mL}$ of phosphate buffer solution were therefore added to $100 \mu \mathrm{L}$ of hemolyzed red cells. The absorbance of the obtained mixture was then measured during $1 \mathrm{~min}$. Consumption of $3.45 \mu \mathrm{mol}$ hydrogen peroxide is characterized by (0.45-0.4) absorbance decrease.

The activity of GPx (U/g Hb) was assayed in erythrocytes by the method of Günzler et al. using t-butyl hydroperoxide $(\mathrm{tBOOH})$ as a substrate [14]. After dilution, $25 \mu \mathrm{L}$ of hemolyzed red cells were added to $900 \mu \mathrm{L}$ of buffer Tris, $20 \mu \mathrm{L}$ of glutathione (GSH), $20 \mu \mathrm{L}$ of glutathion reductase (GSH-Rase) and $20 \mu \mathrm{L}$ of NADPH2. Twenty microliters of $\mathrm{tBOOH}$ were then added and finally, decrease of NADPH2 optical density was followed up at $340 \mathrm{~nm}$.

Coefficients of variation (CV) were $2.9 \%, 3.5 \%$ and $4.9 \%$ for SOD, CAT and GPx activities. An in-house pool of human erythrocytes was used as interval quality control. 


\section{Statistical analysis}

The statistical analysis was performed using the SPSS package (12.0 for Windows). The results are presented as means \pm SD. As recommended in [15], the blood pressure $\mathrm{z}$-scores were calculated in reference to the height. Differences in mean values were evaluated using the one-way analysis of variance (ANOVA). Each variable was examined for normal distribution using the Shapiro-Wilk test. The Pearson's model was used to test associations between the considered variables. Statistical significance was considered at $\mathrm{p}<0.05$.

\section{Results}

Mean variations of anthropometrical data are presented in Table 1. For both gender, the study population has been separated in two groups according to age interval: 6-8.5 and 9-12 years old. The weight, the height and then the BMI are expected to show important age-related variations during childhood and adolescence [9]. Note that the subject group size (n) is nearly the same according to gender and age intervals: The boys/girls ratio is 50:56. The 6-8.5 years and 9-12 years obese/controls ratios are respectively 11:12 and 12:15 (for boys), 13:11 and 18:14 (for girls). For all the children groups, there is no significant difference in mean age between obese and normalweight volunteers (Table 1). No variation in mean height is noteworthy, except for girls aged 9-12 years old (151 \pm $0.1 \mathrm{~cm}$ and $141.5 \pm 0.09 \mathrm{~cm}$ for obese and normal-weight girls respectively, $\mathrm{p}<0.01$ ). However, mean $\mathrm{BMI}$ is shown to be considerably higher in obese children than in controls for all age groups. Significant differences are also obtained in weight mean value for all subject groups. In addition, obese children have higher waist and hip circumferences than normal-weight subjects $(\mathrm{p}<0.05)$. Differences in diastolic and systolic blood pressure according to BMI classification are not significant. Similarly, systolic and diastolic z-scores referred to the height show no significant variation between obese and normalweight children. Plasma total cholesterol is shown to significantly increase in obese children $(\mathrm{p}<0.01$ and $\mathrm{p}<0.001$ respectively for $6-8.5$ and $9-12$ years age intervals). Other fasting biochemical levels including plasma glucose and triglycerides do not show any significant difference between obese and normal-weight children (Table 1). The same remark is available for ageand gender- related variations. For all subgroups, the obtained mean data show a good concordance with the reference values according to the European recommendation guidelines. This confirms the normal health status of the recruited children.

Mean anti-radical enzyme activities according to gender and age interval are summarized in Table 2. The

Table 1 General characteristics of the study population (mean \pm SD)

\begin{tabular}{|c|c|c|c|c|c|c|c|c|}
\hline & \multicolumn{4}{|c|}{ Boys $(n=50)$} & \multicolumn{4}{|c|}{ Girls $(n=56)$} \\
\hline & \multicolumn{2}{|c|}{ Age: 6-8.5 years } & \multicolumn{2}{|c|}{ Age: $9-12$ years } & \multicolumn{2}{|c|}{ Age: $6-8.5$ years } & \multicolumn{2}{|c|}{ Age: $9-12$ years } \\
\hline & $\begin{array}{c}\text { Obese } \\
\text { children } \\
(n=11)\end{array}$ & $\begin{array}{c}\text { Controls } \\
(n=12)\end{array}$ & $\begin{array}{c}\text { Obese } \\
\text { children } \\
(n=12)\end{array}$ & $\begin{array}{c}\text { Controls } \\
(n=15)\end{array}$ & $\begin{array}{l}\text { Obese } \\
\text { children } \\
(n=13)\end{array}$ & $\begin{array}{c}\text { Controls } \\
(n=11)\end{array}$ & $\begin{array}{c}\text { Obese } \\
\text { children } \\
(n=18)\end{array}$ & $\begin{array}{c}\text { Controls } \\
(n=14)\end{array}$ \\
\hline Age (years) & $7.38 \pm 0.86$ & $7.39 \pm 0.85$ & $11.36 \pm 0.67$ & $11.28 \pm 1.32$ & $7.55 \pm 0.92$ & $7.44 \pm 0.90$ & $11.06 \pm 1.24$ & $11.29 \pm 0.48$ \\
\hline Height (cm) & $131.0 \pm 0.1$ & $128.6 \pm 0.1$ & $151.6 \pm 0.06$ & $146.1 \pm 0.12$ & $129.0 \pm 0.06$ & $127.0 \pm 0.07$ & $151.0 \pm 0.1^{\mathrm{a}}$ & $141.5 \pm 0.09$ \\
\hline Weight (kg) & $37.43 \pm 6.37^{b}$ & $25.86 \pm 4.02$ & $63.90 \pm 5.61^{a}$ & $36.07 \pm 8.38$ & $37.83 \pm 7.22^{a}$ & $26.67 \pm 3.56$ & $62.47 \pm 12.72^{b}$ & $33.33 \pm 6.10$ \\
\hline BMI $\left(\mathrm{kg} / \mathrm{m}^{2}\right)$ & $22.28 \pm 2.46^{b}$ & $15.41 \pm 0.98$ & $28.57 \pm 4.28^{b}$ & $17.03 \pm 1.87$ & $23.24 \pm 2.45^{b}$ & $15.81 \pm 1.37$ & $27.44 \pm 2.84^{b}$ & $16.14 \pm 2.10$ \\
\hline $\begin{array}{l}\text { Waist circumference } \\
(\mathrm{cm})\end{array}$ & $68.33 \pm 4.23^{a}$ & $54.5 \pm 2.12$ & $99.0 \pm 4.14^{b}$ & $61.83 \pm 5.74$ & $77.2 \pm 3.83^{b}$ & $53.67 \pm 2.31$ & $87.67 \pm 8.45^{a}$ & $65.0 \pm 8.18$ \\
\hline $\begin{array}{l}\text { Hip circumference } \\
(\mathrm{cm})\end{array}$ & $76.5 \pm 7.31^{a}$ & $63.0 \pm 1.41$ & $98.5 \pm 6.26^{a}$ & $69.5 \pm 5.28$ & $84.25 \pm 6.85^{a}$ & $60.33 \pm 4.2$ & $99.67 \pm 9.46^{a}$ & $75.33 \pm 5.77$ \\
\hline Systolic BP (mm Hg) & $125.0 \pm 5.9$ & $102.5 \pm 3.5$ & $124 \pm 5.7$ & $104.5 \pm 5.8$ & $127.5 \pm 6.5$ & $106.7 \pm 5.8$ & $129.8 \pm 8.0$ & $118.3 \pm 7.6$ \\
\hline Systolic BP z-score & $1.28 \pm 0.68$ & $1.11 \pm 0.88$ & $2.88 \pm 1.1$ & $2.81 \pm 1.2$ & $1.85 \pm 0.82$ & $1.38 \pm 0.53$ & $2.83 \pm 0.61$ & $2.27 \pm 0.47$ \\
\hline Diastolic BP (mm Hg) & $66.7 \pm 5.2$ & $65.7 \pm 7.5$ & $72.5 \pm 5.6$ & $67.5 \pm 2.7$ & $68.8 \pm 7.5$ & $63.3 \pm 5.8$ & $72.5 \pm 5.4$ & $70.0 \pm 6.7$ \\
\hline Diastolic BP z-score & $0.39 \pm 0.19$ & $0.29 \pm 0.16$ & $0.88 \pm 0.18$ & $0.82 \pm 0.21$ & $0.54 \pm 0.18$ & $0.46 \pm 0.1$ & $1.09 \pm 0.46$ & $0.78 \pm 0.37$ \\
\hline Glucose* $^{*}(\mathrm{mmol} / \mathrm{L})$ & $3.86 \pm 0.56$ & $3.97 \pm 0.51$ & $4.24 \pm 0.92$ & $4.42 \pm 0.71$ & $3.70 \pm 0.50$ & $4.04 \pm 0.45$ & $4.57 \pm 0.55$ & $4.45 \pm 0.73$ \\
\hline $\begin{array}{l}\text { Total cholesterol** } \\
(\mathrm{mmol} / \mathrm{L})\end{array}$ & $4.22 \pm 1.21^{a}$ & $3.13 \pm 0.97$ & $4.39 \pm 0.79^{b}$ & $3.05 \pm 0.41$ & $4.29 \pm 1.26^{a}$ & $3.18 \pm 1.17$ & $4.40 \pm 0.31^{b}$ & $3.10 \pm 0.21$ \\
\hline $\begin{array}{l}\text { Triglycerides*** } \\
(\mathrm{mmol} / \mathrm{L})\end{array}$ & $0.95 \pm 0.15$ & $0.85 \pm 0.14$ & $0.98 \pm 0.12$ & $0.82 \pm 0.18$ & $0.92 \pm 0.15$ & $0.79 \pm 0.17$ & $0.94 \pm 0.18$ & $0.82 \pm 0.17$ \\
\hline
\end{tabular}

Normal fasting ranges (according to the European guidelines): ${ }^{*} 3.3-6 \mathrm{mmol} / \mathrm{L} ;{ }^{* *} 4-6 \mathrm{mmol} / \mathrm{L} ;{ }^{* * *} 0.6-1.7 \mathrm{mmol} / \mathrm{L}$.

$B P$ Blood pressure.

${ }^{a}(p<0.01) i^{b}(p<0.001)$. 
Table 2 The mean anti-radical enzyme activities (GPx, SOD and CAT) in obese and normal -weight children (mean \pm SD)

\begin{tabular}{|c|c|c|c|c|c|c|c|c|}
\hline & \multicolumn{4}{|c|}{ Boys } & \multicolumn{4}{|c|}{ Girls } \\
\hline & \multicolumn{2}{|c|}{ Age: 6-8.5 years } & \multicolumn{2}{|c|}{ Age: 9-12 years } & \multicolumn{2}{|c|}{ Age: 6-8.5 years } & \multicolumn{2}{|c|}{ Age: 9-12 years } \\
\hline & $\begin{array}{l}\text { Obese children } \\
(n=11)\end{array}$ & $\begin{array}{c}\text { Controls } \\
(n=12)\end{array}$ & $\begin{array}{l}\text { Obese children } \\
(n=12)\end{array}$ & $\begin{array}{c}\text { Controls } \\
(n=15)\end{array}$ & $\begin{array}{l}\text { Obese children } \\
(n=13)\end{array}$ & $\begin{array}{c}\text { Controls } \\
(n=11)\end{array}$ & $\begin{array}{l}\text { Obese children } \\
(n=18)\end{array}$ & $\begin{array}{c}\text { Controls } \\
(n=14)\end{array}$ \\
\hline $\mathrm{SOD}(\mathrm{U} / \mathrm{mg} \mathrm{Hb})$ & $3.37 \pm 0.96^{*}$ & $2.59 \pm 0.91$ & $3.41 \pm 1.05^{* *}$ & $2.75 \pm 1.03$ & $3.92 \pm 0.79^{*}$ & $3.08 \pm 0.92$ & $4.31 \pm 0.91^{* *}$ & $3.35 \pm 0.78$ \\
\hline GPx (U/g Hb) & $39.77 \pm 6.98$ & $32.48 \pm 7.29$ & $34.38 \pm 8.52$ & $33.83 \pm 8.9$ & $38.83 \pm 7.26$ & $34.41 \pm 6.22$ & $36.55 \pm 6.48$ & $35.64 \pm 8.31$ \\
\hline CAT (U/g Hb) & $32.48 \pm 5.95$ & $30.83 \pm 8.63$ & $32.15 \pm 7.27$ & $29.22 \pm 7.39$ & $32.69 \pm 8.44$ & $31.65 \pm 6.54$ & $39.77 \pm 12.25$ & $38.27 \pm 11.84$ \\
\hline
\end{tabular}

*: $p<0.01 ; * * p<0.05$.

activity of the first-step antioxidant enzyme (SOD) is shown to increase in association with pediatric obesity. For both gender, the SOD activity is significantly higher in obese children than in normal-weight subjects for every age interval. Girls show relatively higher antioxidant SOD activity in comparison with boys $(\mathrm{p}<0.01)$. The mean activities of the second-step anti-radical enzymes (GPx and CAT) do not show any significant difference between obese and normal-weight children in all gender and age-related groups. No significant genderassociated difference is obtained in GPx and CAT activities.

Table 3 shows the correlation coefficients among GPx, SOD and CAT activities, and various parameters (age, BMI, waist and hip circumferences, glucose, total cholesterol and triglycerides). SOD is found to be significantly and positively associated with BMI using the Pearson rank correlation: $\mathrm{r}=0.3(\mathrm{p}=0.04)$ and $\mathrm{r}=0.15(\mathrm{p}=0.036)$ respectively for boys and girls. Associations between the activity of SOD and the remaining parameters are not significant. Variations of GPx and CAT activities according to BMI are not relevant. No significant association is obtained between GPx, SOD or CAT activity, with age, waist and hip circumferences, glucose, total cholesterol and triglycerides serum fasting levels. Partial correlation test adjusted by age has been also performed. The obtained results show that only the SOD activity is significantly correlated with the BMI, for girls $(\mathrm{r}=0.19, \mathrm{p}<0.01)$ and for boys $(\mathrm{r}=0.32, \mathrm{p}=0.05)$.

\section{Discussion}

The relationship between obesity and oxidant stress parameters has been extensively studied in healthy adults. However, it is unknown whether this relationship exists from early age and if it has the same trends during childhood. The response to oxidant damage caused by ROS production differs from age to age: The maturation of antioxidant enzymes is, in fact, related to ageing. In this study, we examined the variations of antioxidant enzyme activities - considered biomarkers of oxidant stress - in a population of healthy obese children. Cases of endogenic obesity were not considered to exclude other factors influencing the antioxidant enzyme activity

Table 3 Correlation coefficients among age, BMI, biochemical levels, and antioxidant enzyme activities

\begin{tabular}{|c|c|c|c|c|c|c|c|}
\hline & & \multicolumn{3}{|c|}{ Boys $(n=50)$} & \multicolumn{3}{|c|}{ Girls $(n=56)$} \\
\hline & & GPx & SOD & CAT & GPx & SOD & CAT \\
\hline \multirow[t]{2}{*}{ Age } & Correlation coefficient & -0.04 & -0.12 & -0.22 & -0.12 & 0.13 & -0.04 \\
\hline & Significance & 0.8 & 0.52 & 0.21 & 0.43 & 0.45 & 0.79 \\
\hline \multirow[t]{2}{*}{ BMI } & Correlation coefficient & 0.17 & $0.3^{*}$ & -0.08 & -0.03 & $0.15^{*}$ & -0.08 \\
\hline & Significance & 0.28 & 0.04 & 0.65 & 0.87 & 0.036 & 0.57 \\
\hline \multirow[t]{2}{*}{ Waist circumference } & Correlation coefficient & -0.05 & 0.18 & -0.11 & -0.23 & 0.03 & 0.11 \\
\hline & Significance & 0.86 & 0.58 & 0.69 & 0.39 & 0.91 & 0.71 \\
\hline \multirow[t]{2}{*}{ Hip circumference } & Correlation coefficient & 0.07 & 0.33 & -0.11 & -0.29 & 0.14 & 0.19 \\
\hline & Significance & 0.81 & 0.28 & 0.69 & 0.28 & 0.62 & 0.51 \\
\hline \multirow[t]{2}{*}{ Glucose } & Correlation coefficient & 0.19 & 0.06 & 0.18 & -0.23 & -0.27 & -0.18 \\
\hline & Significance & 0.41 & 0.83 & 0.48 & 0.26 & 0.16 & 0.43 \\
\hline \multirow[t]{2}{*}{ Total cholesterol } & Correlation coefficient & 0.32 & 0.14 & 0.15 & 0.36 & 0.23 & 0.12 \\
\hline & Significance & 0.28 & 0.35 & 0.19 & 0.16 & 0.52 & 0.26 \\
\hline \multirow[t]{2}{*}{ Triglycerides } & Correlation coefficient & -0.03 & 0.18 & -0.05 & 0.07 & 0.19 & -0.42 \\
\hline & Significance & 0.69 & 0.19 & 0.56 & 0.37 & 0.29 & 0.13 \\
\hline
\end{tabular}

* Significant correlation $(p<0.05)$. 
[16]. A control group composed of healthy normalweight children was established with comparable age and gender-related distributions. Obesity indicators, such as BMI, waist and hip circumferences, were shown to significantly increase in diagnosed obese children. There was also no gender disparity in BMI, waist or hip circumference, in line with previous studies [16-18].

Obesity can be defined as an excess of body fat. There are several methods of measuring the percentage of body fat. In the clinical environment, techniques based on BMI, waist or hip circumference, and skin fold thickness have been extensively used and suggested to be satisfactory in identifying risk [19]. Some authors [20] have suggested using waist circumference since it seems to be more accurate for children: it targets central obesity, which is a risk factor for type II diabetes and coronary heart disease.

This study showed that the antioxidant enzyme activity of SOD was markedly higher in the obese children compared to the normal-weight ones, taking into account the gender and the age-related variations. No significant difference was obtained in the second step enzymes (GPx and CAT) activities. These results confirm the fact that obesity is associated with the oxidant stress increase, even in early age. Possible mechanisms contributing to the obesity-associated oxidant stress include increased oxygen consumption and subsequent radical production via mitochondrial respiration, increased fat deposition and cell injury causing increased rates of radical formation [21]. The cell adaptation to the increase of radical production, as a consequence of obesity, consists then in the increase of SOD activity. In pediatric obesity, only the first-step enzyme (SOD) activity seems to be affected by the increase of body fat. A previous investigation performed on healthy children had also shown that the SOD activity was enhanced in association to obesity [16]. Other studies on animal and human adults showed controversial results. Koboyasi et al. [22] demonstrated that the production of superoxide anion and the $\mathrm{Cu} / \mathrm{ZnSOD}$ activity increased in obese mice. Nakao et al. [23] also reported significant increased SOD levels in the liver, kidney, muscles, plasma, and white and brown adipose tissues of obese mice. Vincent et al. [21] found that the $\mathrm{Cu} / \mathrm{ZnSOD}$ activity in the left ventricles of rats was greater in the obese animals compared to lean controls. Other studies have identified no significant or opposite difference in individual antioxidant enzyme concentrations in obesity. Brown et al. [6] found no significant difference in total antioxidant status, SOD and reduced glutathione among normal-weight, overweight, and obese adults. On the contrary, Olusi [24] found that erythrocyte $\mathrm{Cu} / \mathrm{ZnSOD}$ activity was significantly lower in obese subjects compared to results from control subjects. Similarly, Ozata et al. [25] reported $42 \%$ lower SOD activity in obese vs. non-obese men. These discrepancies could be linked to the duration of obesity. For example, in the development stages of obesity, antioxidant enzymes may be stimulated whereas in chronic and long-term obesity, the sources of antioxidant enzymes become depleted, leading to a low level activity [6]. An example of antioxidant stimulation during the development stages of obesity has been shown in the study of Dobrian et al. [26] who reported increases in the activity of SOD after 10 weeks of diet-induced obesity in rats. The effects of chronic obesity has not been scientifically studied but could be achieved by studying obese individuals of similar weight and body composition and varying degrees of length of obesity time.

The anti-oxidant enzyme activity is subject to various stress-related factors, including physical activity and hypercholesterolemia. Woo et al. [27] investigated the effects of detraining on the antioxidant enzyme in Korean overweight children. They showed, in particular, that the protein and expression of GPx was increased following a 12-week as compared with prior to training. The protein and expression of SOD showed no significant changes. On the other hand, it had been shown that hypercholesterolaemic non-obese children had lower red cell antioxidant enzymes [28]. As a consequence, they could be more susceptible to the adverse effects of reactive oxygen species. In the present study, these factors have not been considered to investigate separately the effect of obesity on the markers of the antioxidant enzyme activity.

In addition, hyperglycemia, hypertension, and hypercholesterolemia are also possible sources of increased oxidant stress in the obese state [29]. The present study showed that the antioxidant enzyme defense was enhanced in obese children, which had normal health parameters including blood pressure, glucose, and triglycerides concentrations. Moreover, the associations between the antioxidant enzyme activities and these biochemical data were not significant. This allows rejecting the hypothesis saying that the obesity-associated oxidant stress is only a consequence of obesity-related diseases [30,31]. Instead, it can be related to the excess in the adipose tissue accumulation. These findings are also confirmed by Keaney et al. [32] who found in a community-based cohort, a strong association between markers of oxidant stress and BMI, implicating adiposity as the main factor for increased oxidant stress.

When the plasma levels of total cholesterol of obese and normal-weight children were compared, there was a significant increase in the obese group. Although, both total cholesterol and SOD levels were significantly higher in obese children, no correlation was observed between the two parameters. Free radicals are very potent oxidants and react with lipids to result in lipid peroxidation [33]. 
Although, the general consensus is that obesity (and increased BMI) increases oxidant stress even during childhood, it is difficult to identify a typical-related oxidant stress response because the majority of studies have incorporated different methodology designs including different oxidant stress markers.

\section{Conclusions}

Obesity is still a major health problem in most countries, particularly in children. Then, defining the basic physiopathology of childhood obesity should be the first step in preventing the associated consequences that may develop lifelong. In particular, it is still unknown whether the cellular defense mechanisms and their influence against many diseases are widely related to obesity and its complications. This study investigated the effect of obesity on the antioxidant body response in healthy children. In support of previous research findings, the oxidant stress resulting from obesity appeared at an early age. In fact, the activity of the first-step enzyme SOD was shown to increase in association with the increased BMI. In addition to obesity-related complications such as hyperlipidemia and diabetes mellitus, obesity itself is an independent risk factor in the matter of free radicals which are known to be responsible for organ damage in many diseases. It would be interesting to identify and test dietary components that can catch or prevent the excess in the production of the reactive oxygen radicals using both clinical and experimental investigations. Other potential research studies may identify suitable strategies to reverse the obesity-associated oxidant stress (weight loss, calorie restriction, exercise training, etc.).

\section{Abbreviations}

SOD: Superoxide dismutase; GPx: Glutathione peroxidase; CAT: Catalase; BMl: Body mass index; ROS: Reactive oxygen species.

\section{Competing interests}

The authors declare that they have no competing interests.

\section{Authors' contributions}

SS Conceived the study, and participated in its design and coordination, performed the statistical analysis, drafted the original manuscript and edited the final paper. RB participated in the design and coordination of the study. MTS provided key insight into the conception and the coordination of the study, and contributed to the final review of the manuscript. AK participated in the coordination of the experimental part of the study. All authors read and approved the final manuscript.

\section{Acknowledgments}

We are grateful to Dr. Chems Eddine Souissi for his assistance in the medical examination and the data collection. We also appreciate the collaboration of the parents whose children participated in this study.

\section{Author details}

${ }^{1}$ Unité de recherche «Eléments trace, radicaux libres, systèmes antioxydants et pathologies humaines», Faculté de médecine de Monastir, Université de Monastir, rue Avicenne, 5019, Monastir, Tunisia. ${ }^{2}$ Service de Pédiatrie, Hôpital universitaire de Mahdia, 5111, Mahdia, Tunisia.
Received: 6 October 2012 Accepted: 25 January 2013

Published: 29 January 2013

\section{References}

1. Juonala M, Juhola J, Magnussen CG, et al: Childhood environmental and genetic predictors of adulthood obesity: the cardiovascular risk in young Finns study. J Clin Endocrinol Metab 2011, 96(9):E1542-1549.

2. Fernandez JR, Klimentidis YC, Dulin-Keita A, Casazza K: Genetic influences in childhood obesity: recent progress and recommendations for experimental designs. Int J Obes (Lond) 2012, 36(4):479-484.

3. Lobstein T, Baur L, Uauy R: Obesity in children and young people: a crisis in public health. Obesity Rev 2004, 5(S1):4-104.

4. Daniels SR, Arnett DK, Eckel RH, et al: Overweight in children and adolescents: pathophysiology, consequences, prevention, and treatment. Circulation 2005, 111(15):1999-2012.

5. Brisbois TD, Farmer AP, McCargar LJ: Early markers of adult obesity: a review. Obes Rev 2012, 13(4):347-367.

6. Brown LA, Kerr CJ, Whiting P, Finer N, McEneny J, Ashton T: Oxidant stress in healthy normal-weight, overweight and obese individuals. Obesity 2009, 17(3):460-466.

7. Dalle-Donne I, Rossi R, Colombo R, Giustarini D, Milzani A: Biomarkers of oxidative damage in human disease. Clin Chem 2006, 52(4):601-623.

8. Cole TJ, Bellizzi MC, Flegal KM, Dietz WH: Establishing a standard definition for child overweight and obesity worldwide: international survey. BMJ 2000, 320:1240-1245.

9. Flodmark CE, Lissau I, Moreno LA, Pietrobelli A, Widhalm K: New insights into the field of children and adolescents' obesity: the European perspective. Int J Obesity 2004, 28:1189.

10. Marklund S, Marklund G: Involvement of the superoxide anion radical in the autooxidation of pyragollol and a convenient assay for superoxide dismutase. Eur J Biochem 1974, 47:469-474.

11. Winterbourn CC, Hawkins RE, Brian M, Carrell RW: The estimation of red cell superoxide dismutase activity. J Lab Clin 1975, 85(2):337-341.

12. Beers RF, Sizer IW: A spectrometric method for measuring the breakdown of hydrogen peroxide by catalase. J Biol Chem 1952, 195(1):133-140.

13. Aebi HE: In Methods of Enzymatic Analysis. Edited by Bergmeyer HU, Bergmeyer J, Grabi M. Germany: Verlagsgesellschaft GmbH; 1983:273-282.

14. Günzler WA, Kremers $H$, Flohé L: An improved coupled test procedure for glutathione peroxidase in blood. J Clin Chem Clin Biochem 1974, 12(10):444-448.

15. National high blood pressure education program working group on high blood pressure in children and adolescent: The fourth report on the diagnosis, evaluation, and treatment of high blood pressure in children and adolescents. Pediatrics 2004, 114:555-576.

16. Erdeve O, Siklar Z, Kocaturk PA, Dallar Y, Kavas GO: Antioxidant superoxide dismutase activity in obese children. Biol Trace Elem Res 2004, 98(3):219-228.

17. Katmarzyk PT, Srinivasan SR, Chen W, Malina RM, Bouchard C, Berenson GS Body mass index, waist circumference, and clustering of cardiovascular disease risk factors in a biracial sample of children and adolescents. BMC Pediatr 2004, 114(2):198-205.

18. Mushtaq MU, Gull S, Abdullah HM, Shahid U, Shad MA, Akram J: Waist circumference, waist-hip ratio and waist-height ratio percentiles and central obesity among Pakistani children aged five to twelve years. BMC Pediatr 2011, 11:105.

19. Dehghan M, Akhtar-Danesh N, Merchant AT: Childhood obesity, prevalence and prevention. Nutr J 2005, 4:24.

20. Schwandt P, Kelishadi R, Haas GM: First reference curves of waist circumference for German children in comparison to the international values: the PEP family heart study. World J Pediatr 2008, 4(4):259-266.

21. Vincent H, Powers S, Dirks A, Scarpace P: Mechanism for obesity-induced increase in myocardial lipid peroxidation. Int J Obes 2001, 25:378-388.

22. Koboyasi R, Akamine EH, Davel AP, Rodrigues MA, Cavalho CR, Rossoni LV: Oxidative stress and inflammatory mediators contribute to endothelial dysfunction in high-fat diet-induced obesity in mice. J Hypertens 2010, 28(10):2111-2119.

23. Nakao C, Ookawara T, Sato Y, et al: Extracellular superoxide dismutase in tissues from obese (ob/ob) mice. Free Radical Res 2000, 33(3):229-241.

24. Olusi SO: Obesity is an independent risk factor for plasma lipid peroxidation and depletion of erythrocyte cytoprotectic enzymes in humans. Int J Obes Relat Metab Disord 2002, 26:1159-1164. 
25. Ozata $M$, Mergen $M$, Oktenli $C$, et al: Increased oxidative stress and hypozincemia in male obesity. Clin Biochem 2002, 35:627-631.

26. Dobrian AD, Davies MJ, Prewitt RL, Lauterio TJ: Development of hypertension in a rat model of diet-induced obesity. Hypertension 2000, 35:1009-1015.

27. Woo J, Shin KO, Yoo JH, Park S, Kang S: The effects of detraining on blood adipokines and antioxidant enzyme in Korean overweight children. Eur J Pediatr 2012, 171(2):235-243.

28. Codoñer-Franch P, Bataller Alberola A, Domingo Camarasa JV, Escribano Moya MC, Valls Bellés V: Influence of dietary lipids on the erythrocyte antioxidant status of hypercholesterolaemic children. Eur J Pediatr 2009, 168(3):321-327.

29. Vincent HK, Taylor AG: Biomarkers and potential mechanisms of obesity-induced oxidant stress in humans. Int J Obes 2006, 30:400-418.

30. Facchini FS, Hua NW, Reaven GM, Stoohs RA: Hyperinsulinemia: the missing link among oxidative stress and age-related diseases? Free Radic Biol Med 2000, 29:1302-1306.

31. Higdon JV, Frei B: Obesity and oxidative stress: a direct link to CVD? Arterioscler Thromb Vasc Biol 2003, 23(3):365-367.

32. Keaney J, Larson $M$, Vasan $R$, et al: Obesity and systemic oxidative stress: clinical correlates of oxidative stress in the Framingham Study. Arterioscler Thromb Vasc Biol 2003, 23:434-439.

33. Morita $M$, Ishida $N$, Uchiyama $K$, et al: Fatty liver induced by free radicals and lipid peroxidation. Free Radic Res 2012, 46(6):758-765.

doi:10.1186/1475-2891-12-18

Cite this article as: Sfar et al: Antioxidant enzymes activities in obese Tunisian children. Nutrition Journal 2013 12:18.

\section{Submit your next manuscript to BioMed Central and take full advantage of:}

- Convenient online submission

- Thorough peer review

- No space constraints or color figure charges

- Immediate publication on acceptance

- Inclusion in PubMed, CAS, Scopus and Google Scholar

- Research which is freely available for redistribution 